\title{
Trends in economic growth, poverty and energy in Colombia: long-run and short-run effects
}

\author{
Alexander Cotte Poveda • \\ Clara Inés Pardo Martínez
}

Received: 23 March 2011 / Accepted: 16 July 2011 / Published online: 17 August 2011

(C) The Author(s) 2011. This article is published with open access at Springerlink.com

\begin{abstract}
This research analyses the long run and short run relationships among economic growth, poverty and energy using the Colombian case. In this study, we use the time-series methodologies. The results regarding the relationship among economic growth, poverty and energy show that increases in gross domestic product and energy supply per capita should lead a decrease of poverty, which should demonstrate that access to modern and adequate energy services help to decrease poverty and to increase economic growth. Moreover, the improvements in energy efficiency have contributed to increase economic growth from an approach of sustainable development. These results are important for the adequate design, formulation and application of policies and strategies that encourage a better energy use to improve economic growth and decrease poverty, especially in developing countries.
\end{abstract}

Keywords Economic development $\cdot$ Economic growth $\cdot$ Energy $\cdot$ Poverty

\footnotetext{
A. Cotte Poveda $(\bowtie)$

Department of Economics, University of Göttingen, Platz der Göttinger Sieben 3, 37073 Göttingen, Germany

e-mail: alexcotte@yahoo.com
}

\author{
A. Cotte Poveda \\ Faculty of Accounting and Administration, University of La Salle, Cra. 2 No. 10-70, Bogotá, \\ Colombia \\ C.I. Pardo Martínez \\ Energy and Climate Studies, Department of Energy Technology, Royal Institute of Technology, \\ KTH, Brinellvägen 68, 100 44, Stockholm, Sweden \\ e-mail: cipmusa@yahoo.com \\ C.I. Pardo Martínez \\ Faculty of Engineering, University of La Salle, Cra. 2 No. 10-70, Bogotá, Colombia
}




\section{Introduction}

A modern and reliable energy system is key strategy to improve economic growth, human development, labour market and quality of life, especially in developing countries. Several studies have evaluated the relationship between economic growth and energy. For example, Lee [36, 37] evaluates this relationship in developed and developing countries identifying that U.S. showed a bi-directional causality, whereas Canada, Belgium, Netherlands and Switzerland indicated uni-directional causality, and developing countries showed both relationships of causality; Balcilar et al. [4] evaluated the causality between energy use and economic growth in G7 countries finding no consistent causal relationship between these two variables; Ozturk et al. [49] used a panel data of economic growth and energy use for 51 countries recognising that the relationship between these variables is no strong. These studies should demonstrate that there is no agreement about the direction of causality between energy use and economic growth measured as the gross domestic product.

In Colombia, the studies on energy have shown different results. Castillo [10] identified that energy use does not play an important and clear role in productivity, and that economic growth is almost completely dependent on capital, [62-64] and [17] have demonstrated that the relationship between energy and gross domestic product (GDP) has shown a trend change from 2003 caused by greater efficiency in the process, change in the fuel used from low to high quality (i.e., from oil to natural gas), an increase in the process of the auto-generation of energy, and a higher contribution in the GDP of other activities with lower energy consumption such as construction and services activities.

Energy sector has become recognized as key strategy to resolve social problems in Colombia such as poverty because this sector could generate a higher and adequate access to an energy system with more efficient and clean energy sources that should help to increase development, economic growth and productivity [62-64]. However, studies on the relationships among economic growth, poverty and energy are limited in Colombia.

With this background, the objective of this paper is to examine the issue of causality among economic growth, poverty and energy for Colombia during the sample period 1975-2008. This study contributes to the existing literature in the following manner. First, we intend to analyse the relationship between economic growth and energy while controlling for changes in the primary factors of production and other sources of growth, such as labour and exports. Second, this study includes variables of poverty and energy with the aim to understand the role of these variables in economic growth.

The rest of the paper is structured as follows: economic growth, poverty and energy trends in Colombia are discussed in Sect. 2. Section 3 shows the model, methodology and data issues. The results and discussion are presented in Sect. 4. Conclusions and policy implications are briefly discussed in Sect. 5 . 


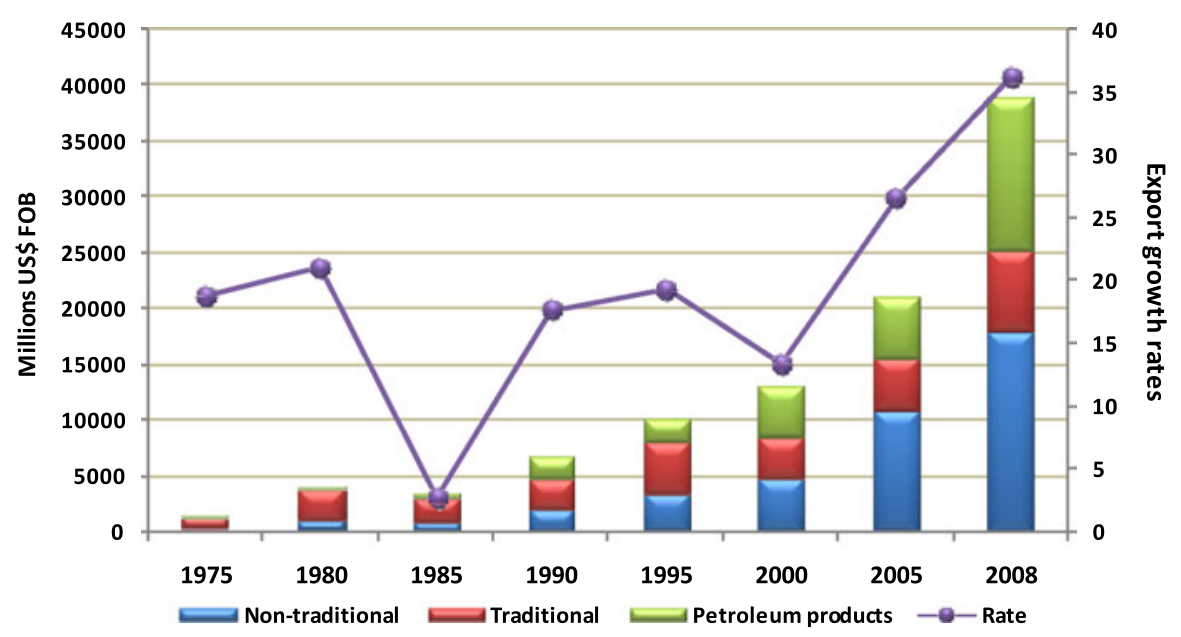

Source: Proexport

Fig. 1 Development of Colombian exportations

\section{Economic growth, poverty and energy trends in Colombia ${ }^{1}$}

During the sample period, the Colombian economy has been rising considerably, despite the fragile conditions exhibited at the end of the 90s. Exportations and investment in conditions of ample liquidity and low interest rates achieved these improvements through consumption. Moreover, during the period 2006-2007 the Colombian economy had the best performance in three decades, surpassing the average for the South American region shown during the last five year an economic growth an average of almost 5\% [9, 43]. Colombian exports have shown sustained growth since 1970 accompanied by high diversification in products (see Fig. 1).

Indicators of the standard of living show that during the sample period poverty have not shown great changes, especially during the 90 s and that poverty increased as a result of the economic recession of 1999. The percentage of Colombian population in poverty conditions decreased from $58.6 \%$ to $48.3 \%$ between 1975 and 2008 (see Fig. 2). However, from 2000, this relationship is unclear [23].

\subsection{Energy matrix}

Between 1975 and 2008, Colombian energy consumption has grown $78.2 \%$ with an average of inter-annual variation rates of $1.8 \%$ for energy consumption and $3.8 \%$ for GDP. Energy intensity ${ }^{2}$ in the last years has shown a decreasing trend as a result of technology change, urbanisation and modernisation, which have led a decrease in the

\footnotetext{
${ }^{1}$ This analysis follows studies and reports by DNP, DANE, CEPAL UPME, and mission to reduce poverty and inequality (MERPD).

${ }^{2}$ Energy intensity is defined as the quantity of energy required per unit of output or activity, when the relations between energy and output decrease over time, energy efficiency has improved [19].
} 


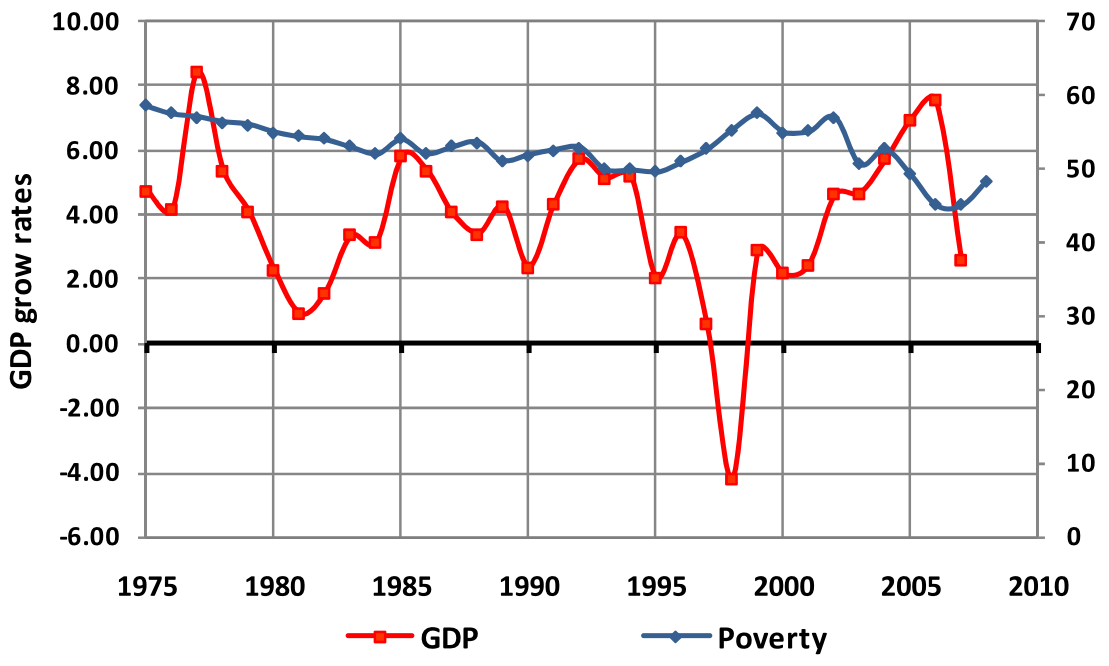

Source: CEPAL and MERPD

Fig. 2 GDP growth rates and poverty in Colombia

use of firewood and its substitution by more efficient and clean fuels, the application of the rational-energy-use programmes and the increase of gas consumption could explain these trends [62-64]. Generally, economic growth has led to increased energy consumption. However, the trends in GDP and energy consumption show a relative decoupling, ${ }^{3}$ although their trends are similar in the Colombian case (see Fig. 3). The relationship between energy consumption and GDP could be affected by substitution between energy and other inputs, technological change, shifts in the composition of energy sources and changes in the composition of output [59].

\subsection{Poverty and energy}

In poverty reduction policies have predominantly strategies based on macroeconomic growth, large-scale infrastructure development and human capital investment. From this strategy, energy has been perceived as a sector that does not determine the decrease of poverty. On the other hand, the current energy-poverty debate establishes that energy and poverty are related $[8,46]$. The trends of energy supply per capita have been increasing alongside the decrease in poverty (see Fig. 4) indicating the close relationship between the decrease in poverty and improvements in energy services where access to modern energy is a fundamental service that enables economic growth and contributes to the success of efforts to eradicate poverty [42].

Moreover, the United Nations, in its report "Road map towards the implementation of the United Nations Millennium Declaration, 2001", includes the following target: "Halve by 2015, the proportion of people without access to electricity and replace

\footnotetext{
${ }^{3}$ Relative decoupling occurs when energy consumption grows, but more slowly than the gross domestic product. Absolute decoupling occurs when energy consumption is stable or falls while GDP grows [20].
} 


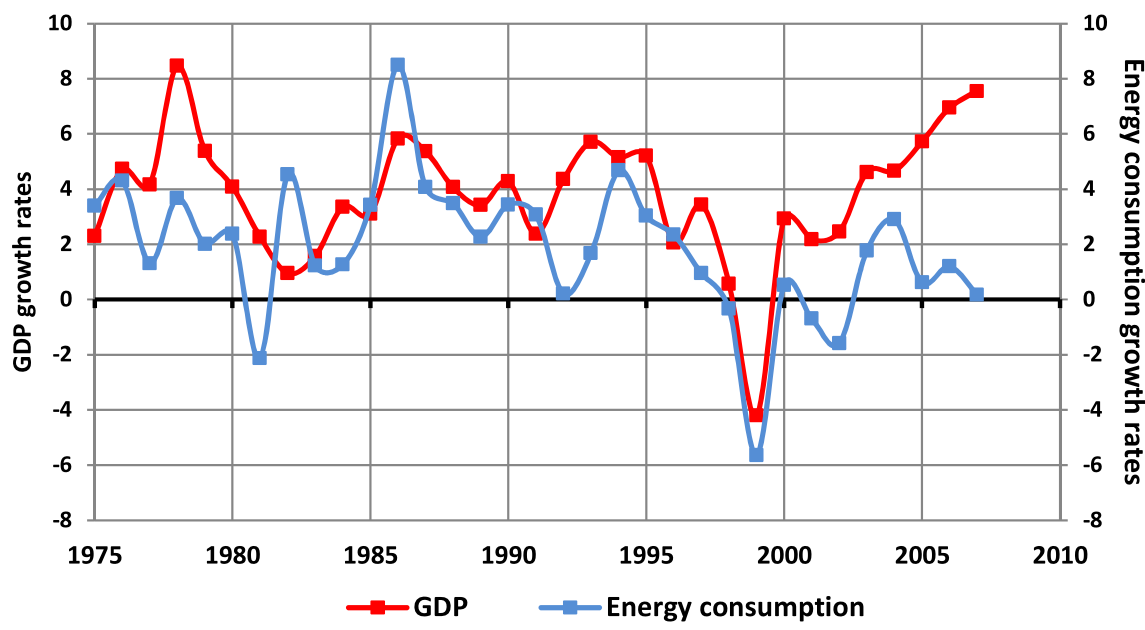

Source: UPME and CEPAL

Fig. 3 Trends of energy consumption and GDP in Colombia

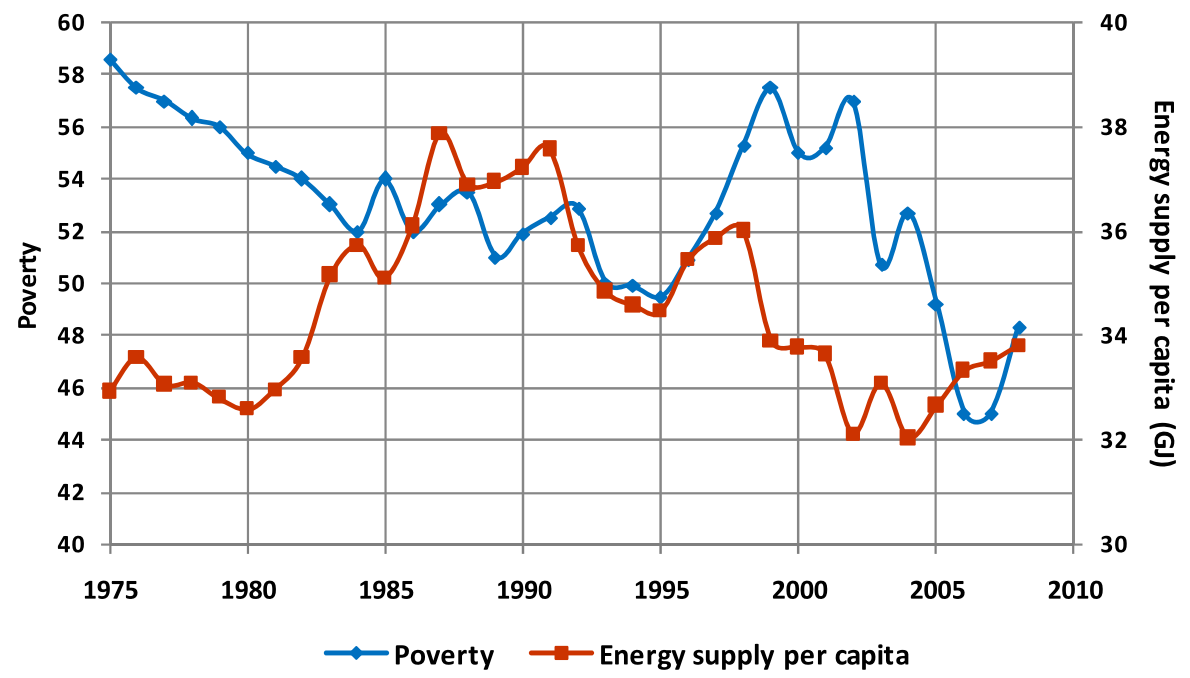

Source: UPME and MERPD

Fig. 4 Poverty and energy supply per capita in Colombia

traditional biomass fuels by cleaner and more efficient energy sources. Whenever applicable, promote the use of renewable energies." This target integrates energy and poverty through goal 9 ("Ensure environmental sustainability") and goal 1 ("Eradicate extreme poverty"), provided that the lack of modern energy services is considered a central characteristic of poverty. 


\section{Methodology}

\subsection{Model}

The influence of energy on economic growth and poverty has become critical after the energy shocks in 1970s, and there has been a recent emphasis on the use of sustainable energy resources as well as a search for energy-efficient production technologies and equipment. The relationship among economic growth and energy is highlighted in a number of studies (see, for example, [10, 38, 45, 50, 53, 60, 68]. These studies apply a production function approach to examine the effect of energy on economic growth. Following Kummel et al. [34, 35] and Ayres [2, 3], the model takes a general production function of the following form:

$$
\begin{gathered}
Y_{t}=f\left(A_{t}, K_{t}, L_{t}, X_{t}, E_{i t}\right)=A_{t} K_{t}^{\alpha} L_{t}^{\beta} X_{t} E_{j t}^{\gamma} \\
0=\alpha, \beta, \eta, \gamma<1
\end{gathered}
$$

where $Y_{t}$ is the total amount of production of the final good at time $t, A_{t}$ is state of technology, $L_{t}$ is total employment, $X_{t}$ is exports, $E_{i t}$ is a variable related to energy (where energy features are energy intensity and energy supply per capita).

Taking logarithm on both sides the equation and including poverty variable, we can write (1) as

$$
\ln Y_{t}=\ln A_{t}+\alpha \ln K_{t}+\beta \ln L_{t}+\ln X_{t}+\gamma \ln E_{t}-\varphi \ln P o v_{t}
$$

Finally, we estimate the following model denominated Output—energy relationship

$$
\ln Y_{t}=\xi+\beta \ln L_{t}+\ln X_{t}+\gamma \ln E_{t}-\varphi \ln \operatorname{Pov}_{t}
$$

Labour is the primary factor of production. The economic theory suggests that increases in labour affect economic growth positively and significantly. Exports are included to capture the effect of external demand or the changes in external environment or openness on domestic economy. The empirical literature and theory suggest positive impact of exports increase on domestic output [33, 47, 69]. The standards of living are also included to capture the impact of poverty in economic growth. The literature provides evidence of a close relationship between economic growth and poverty, with a negative and significant correlation $[1,15,28]$.

In conventional economic theory, energy as a production factor is generally ignored or given low significance because energy's share in the total factor cost is small in comparison to other production factors such as labour or capital. Nevertheless, after the energy crises in 1973/74 and 1979/81, the role of energy in economic growth became an important production factor due to its large economic impact. In order to examine the causality among economic growth, poverty and energy during the sample period (between 1975 and 2008) in Colombia, we use the above model equation (3).

\subsection{Estimation}

In this study, we use time-series estimation that implies the following steps: 


\subsubsection{Test for data stationarity}

In order to determine the stationarity of each series, first, it applies the unit root tests. The tests selected are the following: the Augmented Dickey-Fuller (ADF), PhillipsPerron (PP), Bartlett and Portmanteau white noise tests (see Appendix), which are applied to the data at levels and at first differences. To determine the degree of integration in each of the series analysed.

\subsubsection{Cointegration analysis}

The cointegration tests determine if there exists a long- run relationship among all variables. This test is used to find the stationary linear combinations of vector time series, and in this test a number of cointegrating factors must be determined. If the hypothesis is accepted, the error term $\left(u_{t}\right)$ is not stationary and this means that $y_{t}$ and $x_{t}$ series are not integrated. The latter one is rejected, $y_{t}$ and $x_{t}$ are integrated. Note that since the unit root tests test the null hypothesis of a unit root, most cointegration tests evaluate the null hypothesis of no cointegration. $x_{t}$ and $y_{t}$ are said to be cointegrated if there exists a parameter $\alpha$ such that is a stationary process $[44,58]$.

$$
u_{t}=y_{t i}-\alpha X
$$

Cointegration analysis is used to test the possible long run relation for the variables. The test selected is cointegrating regression Durbin-Watson (CRDW) statistic, which evaluates the stationary of the error terms. This test implies that the data series in each asset class to be integrated to the same order and the presence of a linear combination of the series which is integrated to a lower order than the individual series. That is, the number of times that the series must be differenced to get stationarity is the same across all the data [54]. Then, a third test is performed from the approach of Johansen [30] and Johansen and Juselius [31] to evaluate the number of cointegrating relationships.

\subsubsection{Granger causality tests}

With the results of the previous tests (the stationarity and cointegration), the causality tests are performed using the Granger approach with first-differenced VARs for each of the two pairs. Therefore, two variables $X$ and $Y$, the Granger causality approach is different from the common use of the term, as it evaluates precedence and information provided by $X$ in explaining a current value of $Y$. According to this view, $Y$ is said to be Granger-caused by $X$ if $X$ helps in the prediction of $Y$ or if lagged values of $X$ are statistically significant.

The time series representation of a bivariate VAR for two variables $\mathrm{X}$ and $\mathrm{Y}$ has the following form [18, 24, 25]:

$$
\left[\begin{array}{l}
Y_{t} \\
X_{t}
\end{array}\right]=\left[\begin{array}{l}
C_{1} \\
C_{2}
\end{array}\right]+\left[\begin{array}{ll}
a_{11}^{1} & a_{12}^{1} \\
a_{21}^{1} & a_{22}^{1}
\end{array}\right]\left[\begin{array}{l}
Y_{t-1} \\
X_{t-1}
\end{array}\right]+\cdots+\left[\begin{array}{cc}
a_{11}^{k} & a_{12}^{k} \\
a_{21}^{k} & a_{22}^{k}
\end{array}\right]\left[\begin{array}{c}
Y_{t-k} \\
X_{t-k}
\end{array}\right]+\left[\begin{array}{l}
\varepsilon_{1 t} \\
\varepsilon_{2 t}
\end{array}\right]
$$


where $t$ is the time subscript, $a_{i j}$ are the coefficients of the matrices associated with the VAR, the superscripts denote the order of that matrix, $\Sigma_{t}=\left(\varepsilon_{1 t}, \varepsilon_{2 t}\right)^{\prime}$ is a vector of uncorrelated disturbances and finally $C_{1}$ and $C_{2}$ are constants.

Within a system of two equations, (6) becomes

$$
\begin{aligned}
& Y_{t}=C_{1}+\sum_{i=1}^{K} a_{11}^{i} Y_{t-1}+\sum_{j=1}^{K} a_{12}^{i} X_{t-1}+\varepsilon_{1 t}, \\
& X_{t}=C_{2}+\sum_{j=1}^{K} a_{21}^{i} X_{t-1}+\sum_{i=1}^{K} a_{22}^{i} Y_{t-1}+\varepsilon_{2 t},
\end{aligned}
$$

testing for Granger causality between $X$ and $Y$ consists of checking the significance of the $a_{12}$ and $a_{22}$ coefficients. In other words, $X$ does not Granger-cause $Y$ if the vector $\left(X_{t-1}, X_{t-2}, \ldots, X_{t-k}\right)$ has no power in forecasting $X$. Each equation represented by (6a) and (6b) is estimated separately in testing for Granger causality, and the null hypothesis tested states that $X$ does not Granger-cause $Y$ and $Y$ does not Granger-cause $X$. In the error correction model, the relevant error-correction terms $\left(E C_{t-1}\right)$ are included in the standard Granger causality procedure after all variables have been made stationary by differencing.

\subsubsection{Estimation of the model}

With the results of the unit root test, cointegration and causality, the model is estimated to determine the casual relationship among economic growth, poverty and energy, controlling for changes in labour, exports, standards of living and other energy features. The model selected is ordinary least squares (OLS), which provides certain advantages in this study. First, this model is flexible, easy to estimate, and it usually gives a good fit in the analysis time series. Second, this model takes into account the equations combinating of long-run and short-run information in the data by exploiting the cointegration property.

\subsection{Data}

In this section, the principal definitions of the variables used in this study are shown. The model is estimated using time-series data for the period 1975-2008. The main sources of data are various issues of Energy Balances and Colombian Economic Survey. ${ }^{4}$ The variables are defined as follows: (I) Gross domestic product (GDP) comes from CEPAL is used as the measure of output. The data series is at 2000 price. (II) Labour force comes from the DNP (The Department of National Planning) and is measured as persons in the work force. (III) Exports of goods and services, in millions of dollars, at current FOB prices, are included as a proxy for the openness of the economy. Export expansion is expected to have a positive effect on development and economic growth. (IV) Poverty comes from CEPAL and DNP. (V) Energy supply per

\footnotetext{
${ }^{4}$ Both are published by different entities of Government of Colombia.
} 
capita is calculated as energy supply per person in Colombia as from energy balances of the Unidad de Planeación Minero Energética (Unit of Mining and Energetic Planning, UPME). (VI) Energy intensity is calculated as final energy consumption ${ }^{5}$ per GDP, so that using less energy to produce a product reduces the intensity and factors such as high energy prices, new regulatory requirements, and advances in technology should contribute in the trends of energy intensity $[65,66]$.

\section{Results}

The model used in this study is as follows (Output energy model):

$$
\ln G D P_{t}=\xi+\alpha \ln L a b_{t}+\beta \ln \operatorname{Exp}_{t}+\delta \ln E S P C_{t}-\gamma \ln E I_{t}-\phi \ln P o v_{t}
$$

Note that $G D P_{t}$ is the Gross Domestic Product, $L a b_{t}$ is labour, $E X P_{t}$ are exports, $E S P C_{t}$ is energy supply per capita, $E I_{t}$ is energy intensity, and $P_{o v} v_{t}$ is the poverty.

\subsection{Results of test for data stationarity}

To test the order of integration of the variables we use the standard tests for unit root, namely the Augmented Dickey-Fuller (ADF), the Phillips-Perron (PP), Portmanteau and Bartlett's tests proposed by Dickey and Fuller [16], Phillips and Perron [55], Box and Pierce [7], Ljung and Box [39] and Bartlett [5] respectively. The results of the unit root test are reported in Table 1 indicating that the model must be estimated in levels.

\subsection{Estimation results}

\subsubsection{Long run relationship}

Equation (7) is estimated for Colombia using annual data covering the period of 1975-2008. Table 2 shows results of the long run. The selected model fulfils the standard diagnostic tests (serial correlation, functional form, normality and heteroscedasticity).

The results show that the impact of labour on output is positive (0.063) and marginally significant at the $1 \%$ level. The estimate of the coefficient of exports (0.014) is positive and marginally significant at the 5\% level suggesting that exports flows of Colombia have a stimulating effect on growth. The estimate of the Energy supply per capita bears a positive sign (0.883) and is significant at the $1 \%$ level indicating that economic growth drives energy consumption. The energy intensity variable affects negatively (0.911) real GDP in Colombia. The estimated coefficient is highly significant. Finally, the poverty does not seem to have a significant effect of real GDP. The estimated coefficient is negative $(-0.019)$ and statistically insignificant.

\footnotetext{
${ }^{5}$ Final energy consumption is defined as the sum of the energy supplied (including all energy sources) to the final user for all energy uses. It is calculated as the sum of final energy consumption of all sectors [29, 62-64].
} 


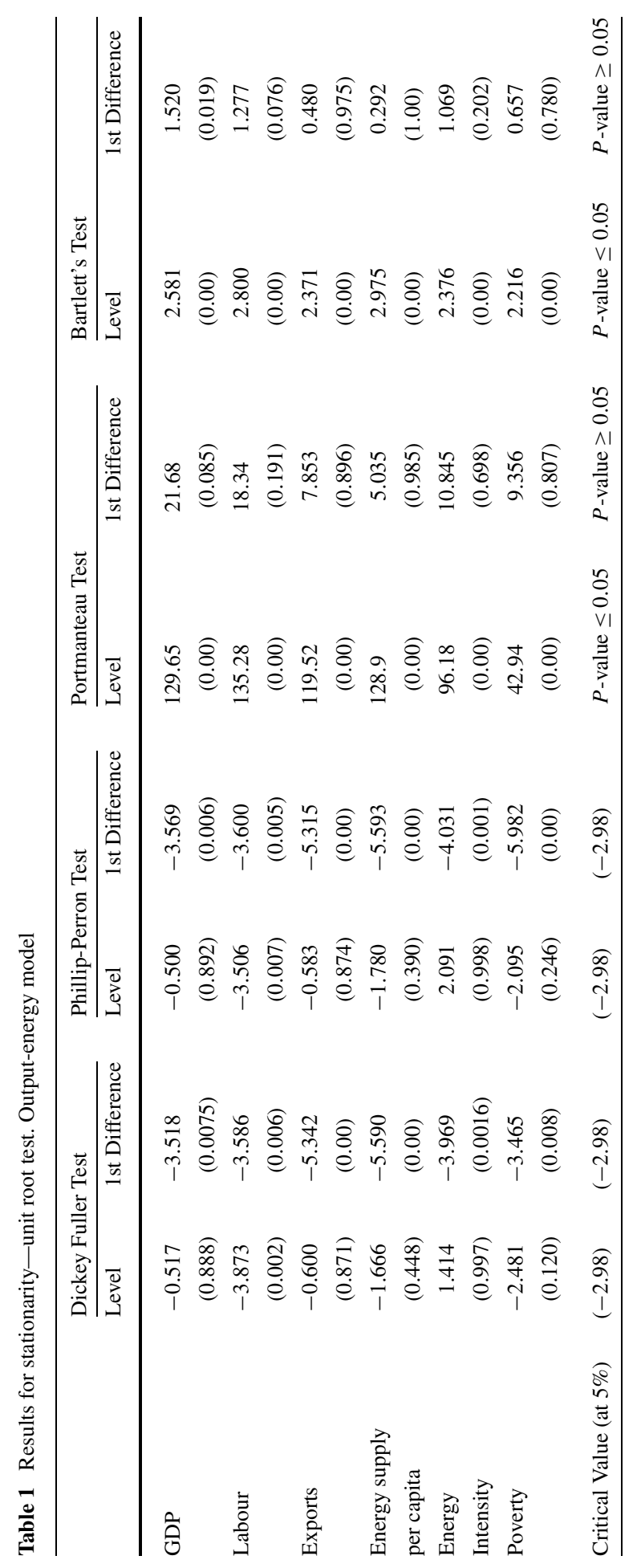


Table 2 Estimated regression model-estimates of the long run coefficients. Output-energy model

\begin{tabular}{lllll}
\hline Dependent variable: real GDP & & & \\
\hline Variables & Coefficients & Stand. error & $t$-ratios & $p$-values \\
\hline Constant & $0.424^{* *}$ & 0.173 & 2.45 & 0.021 \\
Labour & $0.063^{* * *}$ & 0.016 & 3.76 & 0.001 \\
Exports & $0.014^{* *}$ & 0.006 & 2.33 & 0.027 \\
Energy supply per capita & $0.883^{* * *}$ & 0.032 & 27.08 & 0.000 \\
Energy Intensity & $-0.911^{* * *}$ & 0.021 & -43.33 & 0.000 \\
Poverty & -0.019 & 0.014 & -1.39 & 0.175
\end{tabular}

Notes: ${ }^{*}$ Significant at the $10 \%$ level, ${ }^{* *}$ Significant at the $5 \%$ level, ${ }^{* * *}$ Significant at the $1 \%$ level

Table 3 Cointegration tests. Output-energy model

\begin{tabular}{|c|c|c|c|c|}
\hline & $\begin{array}{l}\text { Dickey Fuller } \\
\text { Test }\end{array}$ & $\begin{array}{l}\text { Phillip-Perron } \\
\text { Test }\end{array}$ & CRDW & $\begin{array}{l}\text { Johansen } \\
\text { Trace static }\end{array}$ \\
\hline Gross Domestic Product-Labour & -0.706 & 0.165 & 0.124 & 10.013 \\
\hline Gross Domestic Product-Exports & -0.414 & -2.017 & 0.592 & 11.678 \\
\hline Gross Domestic Product—Energy supply per capita & -0.582 & -0.667 & 0.016 & 3.666 \\
\hline Gross Domestic Product—Energy intensity & -0.960 & -0.897 & 0.099 & 4.772 \\
\hline Gross Domestic Product-Poverty & -1.421 & -1.322 & 0.257 & 7.050 \\
\hline Critical Value (at 5\%) & $(-2.980)$ & $(-2.980)$ & $(0.38)$ & 15.41 \\
\hline Maximum rank & & & & 0 \\
\hline
\end{tabular}

\subsubsection{Short run dynamics}

Table 3 summarises the results of cointegration tests. The absolute values of the calculated test statistics for all the residuals and CRDW are less than its critical value at the $5 \%$ level indicating that neither of the series are cointegrated. Therefore, the standard Granger test [24] is adequate. These results are confirmed by the Johansen likelihood ratio test. The likelihood statistics $(r=0)$ are all well below the $5 \%$ significance level values indicating the acceptance of the null hypothesis.

The results of causality test are reported in Table 4 indicating that growth in the labour, exports and energy supply per capita significantly affect economic growth. The variables in the model are cointegrated indicating that is adequate the use of an error correction model mechanism (ECM) representation in order to evaluate the short run dynamics (see Table 5).

The estimated results of the model are reported in Table 6. The Adj- $R^{2}$ is 0.97 suggesting that such error correction model fits the data reasonably well. More importantly, the error correction coefficient has a negative and highly significant sign. This result confirms a long run relationship among the variables in this model.

The effect of labour is positive on economic growth suggesting that the role of labour in economic growth has been mostly driven by the human capital component, 
Table 4 Granger test for causality. Output-energy model

\begin{tabular}{lccc}
\hline Null Hypothesis & $F$-Value & Probability & Decision \\
\hline Growth in labour force does not cause growth & 10.5 & 0.0004 & Rejected \\
Growth in exports does not cause growth & 5.29 & 0.0110 & Rejected \\
Growth in energy supply per capita does not cause growth & 4.13 & 0.0264 & Rejected \\
Growth in energy intensity does not cause growth & 6.66 & 0.0042 & Rejected \\
Growth in poverty does not cause growth & 9.10 & 0.0009 & Rejected \\
\hline
\end{tabular}

Table 5 Test residuals

\begin{tabular}{llccc}
\hline Variable & Dickey Fuller Test & Lags & Bartlett's Test & Portmanteau Test \\
\hline Residual & -6.145 & 0 & 0.45 & 13.592 \\
& $(0.000)$ & & $(0.986)$ & $(0.556)$ \\
\hline
\end{tabular}

Table 6 Estimated regression model-estimates of the error correction representation. Output-energy model

\begin{tabular}{lcccc}
\hline Dependent variable: real GDP & & & & \\
\hline Variables & Coefficients & Stand. error & $t$-ratios & $p$-values \\
\hline Constant & 0.000 & 0.001 & 0.66 & 0.513 \\
Labour & 0.043 & 0.030 & 1.42 & 0.168 \\
Exports & $0.016^{* * *}$ & 0.005 & 2.93 & 0.007 \\
Energy supply per capita & $0.871^{* * *}$ & 0.040 & 21.35 & 0.000 \\
Energy Intensity & $-0.882^{* * *}$ & 0.035 & -24.99 & 0.000 \\
Poverty & -0.018 & 0.018 & -0.99 & 0.330 \\
Residual (-1) & $-1.089^{* * *}$ & 0.201 & -5.40 & 0.000 \\
Adj-R-squared & 0.97 & & & \\
$F$-value & 212.52 & & & \\
\hline
\end{tabular}

Notes: ${ }^{*}$ Significant at the $10 \%$ level, ${ }^{* *}$ Significant at the $5 \%$ level, ${ }^{* * *}$ Significant at the $1 \%$ level

with raw labour playing a secondary role, which concurs with studies of economic growth in Latin American and Colombian context [11, 14, 40, 43]. In the case of exports with positive and significant effect on economic growth, the results could be explained by the dynamics of Colombian exports, which, during the sample period, were characterised by growth, deceleration and diversification (exports per capita grew at an average rate of $15.5 \%$ in the 1970 s, when the economy was growing, despite the fact that deceleration almost tripled between 1990 and 2005 [43]). According to the measure of export sophistication, EXPY, proposed by Hausmannet et al. [26] the level of Colombia's current export basket sophistication appears moderate but is increasing over time. However, overall export growth has not been enough to result in the sustained growth of exports as a share of GDP, and placecountryregionColombia's exports are small relative to the size of its economy [27]. 
The poverty variable has a negative effect on output indicating the importance of these variables in economic growth. Poverty reduction depends on the growth of average income and on how income is distributed and is closely linked to the sensitivity of poverty to both $[6,12,13,32,41,56,57]$.

Energy supply per capita positively affects economic growth. The variable of energy intensity shows that trends in energy prices, energy policies and technologies have achieved to reduce energy to produce a good during the sample period. Colombia as a developing country shows a moderate technology level with great potential to adopt new technologies to aim of increasing productivity and optimising energy consumption [51, 52, 61].

From the above results, we can see that higher economic growth increases energy supply per capita and decrease poverty. Designing, adopting and implementing policies focused on providing affordable, clean and reliable energy acts should generate economic growth and poverty reduction because access to energy services generates incomes and employment and can help to achieve a more sustainable use of natural resources and improvements in quality of life of population [67].

\section{Conclusions}

In this paper, we studied the direction of the causal relationship between economic growth, poverty and energy in Colombia. Moreover, other variables were analysed such as exports, poverty and energy intensity on economic growth. The methodology used included the Granger causality test, which has been found appropriate by using the co-integration technique and discovering there is no co-integration between the variables concerned.

The results of the long run relationship and short run dynamics show that the effect of labour and exports are a positive effect on output. Also, these two variables are significant in the long run. Exports show the dynamic of this variable in Colombia that during the sample period was characterised by growth, deceleration and diversification. The poverty variable has a negative on output, indicating the importance of this variable for economic growth. Energy intensity has a negative effect on output, showing that improvements in energy efficiency have contributed to increase economic growth from an approach of sustainable development.

The results of energy supply per capita show that this variable contributes in the increase of economic growth, whereas poverty contributes in the decrease of economic growth. From this analysis, we can see that economic growth led energy supply per capita and could contribute in improvements of standard of living. In order to achieve high economic growth and decrease poverty, multidimensional policies are required. These policies should not ignore the energy sector or sustainable development.

In future research will be important include the long run relationship and short run dynamics of economic growth, energy and pollution taking into account the environmental impacts caused by the different fuels used to produce energy and the effects of fuel substitution in the trends of energy use, energy intensity and economic growth. 
Acknowledgements The authors are grateful for the support provided by the University of Göttingen, Royal Institute of Technology (KTH), and University of La Salle. Additionally, the authors would like to thank to Prof. Stephan Klasen, Prof. Semida Silveira, anonymous reviewers and participants of the 17 annual conference of the International Sustainable Development Research Society (University of Columbia, May 8-10/2011) for their valuable comments and suggestions. Any remaining errors are the responsibility of the authors.

Open Access This article is distributed under the terms of the Creative Commons Attribution Noncommercial License which permits any noncommercial use, distribution, and reproduction in any medium, provided the original author(s) and source are credited.

\section{Appendix: Description of unit root tests}

\section{A.1 Augmented Dickey-Fuller (ADF) tests}

If the variable is an $\operatorname{AR}(p)$, as in (1), the process is integrated when $\alpha(1)=1-$ $\alpha_{1}-\cdots-\alpha_{p}=0$. In other words, a hypothesis of interest is $\alpha(1)=0$. To test this null hypothesis against the alternative of the stationary of the process, it is useful to reparametrise the model. Subtracting $Y_{t-1}$ from both sides and rearranging terms results in a regression

$$
\Delta Y_{t}=\phi Y_{t-1}+\sum_{j=1}^{p-1} \alpha_{j}^{*} \Delta Y_{t-j}+u_{t},
$$

where $\varphi=-\alpha(1)$ and $\alpha_{j}^{*}=-\left(\alpha_{j}+1+\cdots+\alpha_{p}\right)$. In this model, we wish to test the pair of hypotheses HO: $\varphi=0$ versus Hl: $\varphi<0$. The so-called augmented DickeyFuller (ADF) test statistic is based on the t-statistic of the coefficient $\varphi$ from an OLS estimation of (3) [22] and [16].

\section{A.2 Phillips-Perron unit root tests}

The test regression for the Phillips and Perron [55] tests (PP) is

$$
\Delta Y_{t}=\beta^{D_{t}}+\pi Y_{t-1}+u_{t},
$$

where $u_{t}$ is $I(0)$ and may be heteroscedastic. The PP tests correct for any serial correlation, and heteroscedasticity in the errors $u_{t}$ of the test regression by directly modifying the test statistics $t_{\pi=0}$ and $T \hat{\pi}$.

\section{A.3 Portmanteau test for white noise}

The portmanteau test depends on the fact that if $x(1), \ldots, x(n)$ is a realization from a white-noise process. Then

$$
Q=n(n+2) \sum_{j=1}^{m} \frac{1}{n-j} \widehat{\rho}^{2}(j) \rightarrow \chi_{m}^{2}
$$

where $m$ is the number of autocorrelations calculated (equal to the number of lags specified) and $\rightarrow$ indicates convergence in distribution to a $\chi^{2}$ distribution with $m$ degrees of freedom. $\widehat{\rho}^{2}$ is the estimated autocorrelation for lag $j$. 


\section{A.4 Bartlett's test for white noise}

Given a time series data set $X_{1}, \ldots, X_{n}$, one of the first things an analyst should do is to test the null hypothesis that the data come from a white noise process of uncorrelated random variables having a constant mean and constant variance. One common method for doing this test is referred to as Bartlett's test [5, 48].

1. Calculate the periodogram of the data set, that is

$$
\hat{f}\left(w_{j}\right)=\frac{1}{n}\left|\sum_{t=1}^{n}\left(X_{t}-\bar{X}\right) e^{2 \pi i(t-1) w_{j}}\right|^{2}
$$

at the frequencies $w_{j}=(j-1) / n, j=1, \ldots, q=[n / 2]+1$. Under the null hypothesis of white noise, except for the values at frequencies 0 and 0.5 , these values should look like a random sample from a constant multiple of a $\left(\chi_{2}^{2}\right.$ distribution $\hat{f}(0)=0$ and $\hat{f}(0.5)$ is a multiple of a $\left.\chi_{1}^{2}\right)$.

2. From the periodogram calculate the cumulative periodogram

$$
\hat{F}\left(w_{k}\right)=\frac{\sum_{j=1}^{k} \hat{f}\left(w_{j}\right)}{\sum_{j=1}^{q} \hat{f}\left(w_{j}\right)}, \quad k=1, \ldots, q
$$

Note that $\hat{F}(0)=0, \hat{F}\left(w_{q}\right)=1$ and under white noise, a plot of the cumulative periodogram versus frequency should fall randomly along a line from $(0,0)$ to $(0.5,1)$.

3. To measure the deviation of $\hat{F}$ from the expected straight line, we calculate

$$
B=\sqrt{q} \max _{1 \leq k \leq q}\left|\hat{F}\left(w_{q}\right)-\frac{k}{q}\right|
$$

Under white noise,

$$
\lim _{n \rightarrow 8} \operatorname{Pr}(B \leq b)=\sum_{j=-\infty}^{\infty}(-1)^{j} e^{-2 b^{2} j^{2} t i \theta}=G(b)
$$

Thus, the null hypothesis of white noise is rejected if the calculated value of $B$ leads to a $\rho$-value calculated from the cdf $G$ less than a specified $\alpha$.

\section{References}

1. Adams, R.: Economic growth, inequality, and poverty: estimating the growth elasticity of poverty. World Dev. 32, 1989-2014 (2004)

2. Ayres, R.: Sustainability economics: where do we stand? Ecol. Econ. 67, 281-310 (2008)

3. Ayres, R.: Energy intensity, efficiency and economics. Lecture for IMF Research Department (2010). http://cedm.epp.cmu.edu/files/slides/Ayres.pdf

4. Balcilar, M., Ozdemir, Z., Arslanturk, Y.: Economic growth and energy consumption causal nexus viewed through a bootstrap rolling window. Energy Econ. 32, 1398-1410 (2010) 
5. Bartlett, M.S.: An Introduction to Stochastic Processes with Special Reference to Methods and Applications. Cambridge University Press, Cambridge (1955)

6. Bourguignon, F.: The growth elasticity of poverty reduction: explaining heterogeneity across countries and time periods. In: Eichner, T., Turnovsky, S. (eds.) Inequality and Growth: Theory and Policy Implications. MIT Press, Cambridge (2003)

7. Box, G., Pierce, D.: Distribution of residual autocorrelations in autoregressive-integrated moving average time series models. J. Am. Stat. Assoc. 65, 1509-1526 (1970)

8. Brook, P., Besant-Jones, J.: Reaching the poor in the age of energy reform. In: Energy Services for the World Poor, Energy and Development Report 2000 (ESMAP). World Bank, Washington (2000)

9. Cardenas, M.: Economic growth in Colombia: a reversal of 'fortune'? Ens. Polit. Econ. 25, 220-259 (2007). Edición Especial Productividad Y Crecimiento

10. Castillo, M.: Energy, capital and technological change in Colombia: a comparative analysis with the United States. J. Univ. Los Andes, 67-72 (1997)

11. Chumacero, R., Fuentes, R.: Economic growth in Latin America: structural breaks or fundamentals? Estud. Econ. 33, 141-154 (2006)

12. Cotte, A.: Estimating effectiveness of the control of violence and socioeconomic development in Colombia: an application of dynamic data envelopment analysis and data panel approach. Social Indicators Research 103(2), 10-34 (2011)

13. Cotte, A.: Economic development and growth in Colombia: an empirical analysis with superefficiency DEA and panel data models. Socio-Econ. Plan. Sci. (2011). doi:10.1016/j.seps.2011.07. 003

14. Cotte, A., Cotrino, J.: Economic growth and income distribution in Colombia. As affected by human capital and the level of education. Cuad. Adm. 19, 337-356 (2006) (in Spanish)

15. Cotte, A., Pardo, C.I.: Poverty and Inequality trends: evidence from Colombian departments. Ens. Rev. Econ. 31 (2011, in press) (in Spanish)

16. Dickey, D., Fuller, W.: Distribution of the estimators for autoregressive time series with a unit root. J. Am. Stat. Assoc. 74, 427-431 (1979)

17. Electricity Interconnection (ISA): Analysis of GDP and energy demand in Colombia in moments of economic crisis (2009). Report 06 (in Spanish)

18. Engle, R.F., Granger, C.W.J.: Co-integration and error correction: representation, estimation and testing. Econometrica 55, 251-276 (1987)

19. European Parliament and European Council on energy end use efficiency and energy services. Directive 2006/32/EC. Off. J. Eur. Union (2006)

20. European Environment Agency (EEA): Indicators and fact sheets about Europe's environment. EN17 Total Energy Intensity (2006). http://www.eea.europa.eu/data-and-maps/indicators/ en17-total-energy-intensity

21. Fleay, B.: Energy quality and economic effectiveness (2005). http://www.aspo-australia.org.au

22. Fuller, W.: Introduction to Statistical Time Series. Wiley, New York (1976)

23. Gomez, W., Torres, A.: Distribution, economic growth and poverty in Colombia: recently discussion and some perspectives to medium run. Perf. Coyunt. Econ. 7, 25-44 (2006) (in Spanish)

24. Granger, C.W.J.: Investigating causal relations by econometrics models and cross spectral methods. Econometrica 37, 424-438 (1969)

25. Granger, C.W.J.: Some recent developments in a concept of causality. J. Econom. 39, 199-211 (1988)

26. Hausmann, R., Hwang, J., Rodrik, D.: What you export matters. NBER Working Paper 11905, National Bureau of Economic Research, Cambridge, MA (2006)

27. Hausmann, R., Klinger, B.: Achieving export-led growth in Colombia. Mimeo (2007)

28. Iceland, J.: A Handbook Poverty in America, 2nd edn. University of California, Los Angeles (2005)

29. International Energy Agency (IEA): Energy Statistics Manual (2005). http://www.iea.org/stats/docs/ statistics_manual.pdf

30. Johansen, S.: Statistical analysis of cointegration vectors. J. Econ. Dyn. Control 12, 231-254 (1988)

31. Johansen, S., Juselius, K.: Maximum likelihood estimation and inference on cointegration-with application to the demand for money. Oxf. Bull. Econ.Stat. 52, 169-210 (1990)

32. Klasen, S.: In search of the holy grail: how to achieve pro-poor growth? In: Tungodden, B., Stern, N., Kolstad, I. (eds.) Toward Pro-Poor Policies: Aid, Institutions, Globalization, pp. 63-93. Oxford University Press, New York (2004)

33. Konya, L.: Exports and growth: Granger causality analysis on OECD countries with a panel data approach. Econ. Model. 23, 978-992 (2006)

34. Kummel, R., Strassl, W., Gossner, A., Eichhorn, W.: Technical progress and energy dependent production functions. J. Econ. 45, 285-311 (1985) 
35. Kummel, R., Henn, J., Lindenberger, D.: Capital, labor, energy and creativity: modeling innovation diffusion. Struct. Change Econ. Dyn. 13, 415-433 (2002)

36. Lee, C.: Energy consumption and GDP in developing countries: a co-integrated panel analysis. Energy Econ. 27, 415-427 (2005)

37. Lee, C.: The causality relationship between energy consumption and GDP in G-11 countries revisited. Energy Policy 34, 1086-1093 (2006)

38. Lindenberger, D., Kummel, R.: Energy-dependent production functions and the optimization model "PRISE" of price-induced sectoral volution. Int. J. Appl. Thermodyn. 5, 101-107 (2002)

39. Ljung, G., Box, G.: On a measure of lack of fit in time series models. Biometrika 65, 297-303 (1978)

40. Loayza, N., Fajnzylber, P., Calderon, C.: Economic growth in Latin America and the Caribbean. Stylized Facts, Explanations and Forecasts. The World Bank, Washington (2005)

41. Lopez, J.: Pro-poor pro-growth: is there a trade-on? Policy Research Working Paper 3378, World Bank (2004)

42. Manlove, K.: Energy poverty 101. Center for American Progress (2009). www.americanprogress.org/ issues/2009/05/energy_poverty $101 . h t m l$

43. Melendez, M., Harker, A.: Revisiting Economic Growth in Colombia-A Microeconomic Perspective. Inter-American Development Bank and Fedesarrollo, IDB Project: Competitiveness and Growth in Latin America (2008)

44. Mencet, N., Firat, Z., Sayin, C.: Cointegration analysis of wine export prices for France, Greece and Turkey. Paper prepared for presentation at the 98 th EAAE Seminar 'Marketing Dynamics within the Global Trading System: New Perspectives' (2006)

45. Moroney, J.: Energy, capital and technological change in the United States. Resour. Energy 14, $363-$ $380(1991)$

46. Najam, A., Cleveland, C.: Energy and sustainable development at global environmental summits: an evolving agenda. Environ. Dev. Sustain. 5, 117-138 (2003)

47. Narayan, P., Smyth, R.: Multivariate granger causality between electricity consumption, exports and GDP: Evidence from a panel of Middle Eastern countries. Energy Policy 37, 229-236 (2009)

48. Newton, H: TIMESLAB: A Time Series Analysis Laboratory, Wadsworth, Inc. (1988)

49. Ozturk, I., Aslan, A., Kalyoncu, H.: Energy consumption and economic growth relationship: evidence from panel data for low and middle income countries. Energy Policy 38, 4422-4428 (2010)

50. Pardo, C.I., Cotte, A.: Energy efficiency in the Colombian manufacturing industries: estimation with data envelopment analysis (DEA) and panel data. Econ. Gest. Desarro. 11, 39-58 (2011) (in Spanish)

51. Pardo Martínez, C.I.: Energy efficiency developments in the manufacturing industries of Germany and Colombia, 1998-2005. Energy Sustain. Dev. 13, 189-201 (2009)

52. Pardo Martínez, C.I.: Energy efficiency development in German and Colombian non-energy-intensive sectors: a non-parametric analysis. Energy Effic. (2010). doi:10.1007/s12053-010-9078-2

53. Paul, S., Bhattacharya, R.: Causality between energy consumption and economic growth in India: a note on conflicting results. Energy Econ. 26, 977-983 (2008)

54. Perman, R.: Co-integration: an introduction to the literature. J. Econ. Stud. 18, 3-30 (1991)

55. Phillips, P., Perron, P.: Testing for unit roots in time series regression. Biometrika 75, 335-346 (1988)

56. Ravallion, M.: Can high inequality development countries escape absolute poverty? Econ. Lett. 56, 51-57 (1997)

57. Ravallion, M.: Pro-poor growth: a primer. Policy Research Working Paper 3242, World Bank (2004)

58. Saunders, P., Biswas, B., Mohapatra, S.: A cointegration analysis of the impact of real exchange rate variations on US agricultural exports. Agric. Financ. Rev. 59, 19-30 (1999)

59. Stern, D., Cleveland, C.: Energy and economic Growth. Working Papers in Economics, Department of Economics, Rensselaer Polytechnic Institute. Number 0410 (2004)

60. Stresing, R., Lindenberger, D., Kummel, R.: Cointegration of output, capital, labor, and energy. Eur. Phys. J. B 66, 279-287 (2008)

61. United Nations Industrial Development Organization (UNIDO): Policies for promoting industrial energy efficiency in developing countries and transition economies. Commission for Sustainable Development (CSD-15) (2007)

62. Unit of Mines and Energy Planning (UPME): Petroleum Chain in Colombia (2007) (in Spanish)

63. Unit of Mines and Energy Planning (UPME): National Energy Plan 2006-2025. Context and Strategies (2007). http://www.upme.gov.co/English/Docs/

64. Unit of Mines and Energy Planning (UPME): Ministry of Mines and Energy, National Energy Balances 1975-2006 (2007) (in Spanish)

65. U.S. Chamber of Commerce Institute for 21st Century Energy (USCCCE): Aggressively promote energy efficiency (2010). http://www.energyxxi.org/issues/Improve_Energy_Efficiency.aspx 
66. U.S. Department of Energy (USDE): Energy efficiency and renewable energy planning, budget, and analysis - energy intensity indicators (2010). http://www1.eere.energy.gov/ba/pba/ intensityindicators/efficiency_intensity.html

67. World Bank: Energy poverty issues and G8 actions. Discussion Paper (2006). http://194.84.38.65/ files/eswfiles/energypoverty

68. Yuan, C., Liu, S., Wu, J.: Research on energy-saving effect of technological progress based on CobbDouglas production function. Energy Policy 37, 2842-2846 (2009)

69. Zestos, G., Tao, X.: Trade and GDP growth: causal relations in the United States and Canada. South. Econ. J. 68, 859-874 (2002) 